\title{
The Influence of Weather Anomalies on Mercury Cycling in the Marine Coastal Zone of the Southern Baltic-Future Perspective
}

\author{
Magdalena Beldowska
}

Received: 4 February 2014 / Accepted: 24 November 2014 /Published online: 11 December 2014

(C) The Author(s) 2014. This article is published with open access at Springerlink.com

\begin{abstract}
Despite the decreased emission loads of mercury, historical deposits of this metal in various compartments of the environment may become an additional diffuse source in the future. Global climate change manifests itself in the temperate zone in several ways: warmer winters, shorter icing periods, increased precipitation and heightened frequency of extreme events such as strong gales and floods, all of which cause disturbances in the rate and direction of mercury biogeochemical cycling. The present study was conducted at two sites, Oslonino and Gdynia Orlowo (both in the coastal zone of the Gulf of Gdansk), from which samples were collected once a month between January 2012 and December 2012. In the Southern Baltic region, climate changes can certainly enhance coast to basin fluxes of mercury and the transfer of bioavailable forms of this metal to the food web. They may also, in the future, contribute to uncontrollable increases of mercury in the seawater.
\end{abstract}

Keywords Mercury . Weather anomalies · Climate change $\cdot$ Storms $\cdot$ Coastal zone $\cdot$ Baltic sea

\section{Introduction}

Despite the unequivocal usefulness of mercury in many branches of industry, this element is characterised by

M. Bełdowska $(\bowtie)$

Institute of Oceanography, University of Gdansk, Av. Piłsudskiego 46, 81-378 Gdynia, Poland e-mail: m.beldowska@ug.edu.pl high toxicity. Indeed, it is the second most toxic heavy metal, after plutonium. So far, no positive functions of mercury have been identified in organisms. On the contrary, as a highly neurotoxic substance, it causes the development of autism in children, while in adults it is responsible for, among other things, Alzheimer's, Parkinson's, Lupus and amyotrophic lateral sclerosis (Zahir et al. 2005). Humans have used mercury for thousands of years but, since the early twentieth century, its usage has increased rapidly in many branches of industry. Only in the 1950s, when several hundred of people died after consumption of mercury-enriched fish, did humanity realise how toxic mercury actually is (Ebinghaus et al. 1999). This and similar disasters brought a concerted effort to restrict its usage and decrease its emissions into the environment through various anti-pollution policies.

In recent papers, the influence of climate change on mercury biogeochemical cycles in the Northern region has been widely discussed (Barkay and Poulain 2007; Stern et al. 2012; Douglas et al. 2012). In most areas, mercury emissions into marine or lacustrine environments have been observed to decrease (Korpinen et al. 2010; Pacyna et al. 2010); however, mercury concentration in fish does not decrease proportionally and in some areas even increases (Carrie et al. 2009b; Fjeld and Rognerud 2011). One of the reasons for this may be an enhanced transfer of metals from terrestrial to marine environments, as has been observed in Arctic and subarctic water bodies, where mercury transported through the atmosphere from the northern hemisphere was deposited in peats for decades. Present day climate 
warming in this area tends to result in the defrosting of peatlands located in permafrost and, together with melt water and mud, historical mercury deposits stored therein are subsequently transported into various water bodies (Barkay and Poulain 2007; Fjeld and Rognerud 2011; Hermanns et al. 2011; Rydberg et al. 2011; Stern et al. 2012; Douglas et al. 2012). Intense rains also contribute to enhanced mercury leaching from river catchments, as was noted in the Mackenzie River (Canada) by Carrie et al. (2009a). When terrestrial mercury enters a water body by such means, the water is also under the influence of climate. For example, it has been proven that algae development and mercury accumulation are higher during warmer and wetter periods than during colder and drier periods (Fjeld and Rognerud 2011; Hermanns et al. 2011; Rydberg et al. 2011). Climate warming also induces increase in plankton biomass, which may result in elevated mercury concentrations in fish (Carrie et al. 2009b), and as was observed in Kusawa Lake (Canada) and some arctic lakes, heightened metal input to sediments (Sanei et al. 2009; Stern et al. 2009). There are a few studies describing the consequences of weather anomalies on the cycles of contaminants (Barkay and Poulain 2007; Douglas et al. 2012; Heimbürger et al. 2010; Stern et al. 2012). However, no studies have so far been published concerning the reemission or remobilisation of mercury (due to climate change) in the southern zone of the Baltic Sea or, for that matter, anywhere else in the temperate zone.

According to HELCOM's report, mercury input to the Baltic Sea has decreased by $44 \%$ since the 1990 s (Korpinen et al. 2010). Additionally, as a result of climate changes in the Polish coastal zone which have increased the frequency of mild winters (i.e., more days warmer than $5{ }^{\circ} \mathrm{C}$ and less colder than $0{ }^{\circ} \mathrm{C}$ ) and rainy summers (Kożuchowski 2009; IMGW PIB Institute of Meteorology and Water Management National Research Institute 2013; HELCOM 2013), mercury load from the region's main source, fossil fuel combustion, has decreased (Bełdowska et al. 2012). On the other hand, though, a longer ice-free period in the Gulf of Gdansk means a longer biologically active season, and this greatly influences the biogeochemical cycles of contaminants contained therein. Furthermore, a heightened frequency of extreme weather events, such as storms and floods, has contributed to an increased load of chemical substances entering the waters of the coastal zone (IMGW PIB Institute of Meteorology and
Water Management National Research Institute 2013; HELCOM 2013). The aim of this study was to observe the tendency of possible shift in mercury cycle under the influence of climate change in the coastal zone of a boreal environment

\section{Material and Methods}

The study area was situated in Oslonino, in the coastal zone of the Gulf of Gdansk (Southern Baltic) (Fig. 1), where a station was located in a small bay with restricted water exchange. The shallow depth and structure of the bay enhance intensive growth processes in aquatic organisms and this, combined with low water dynamics, results in the accumulation of organic matter. This had a direct influence on the physical and chemical conditions (light and dissolved oxygen) prevailing at the station (Korzeniewski 1993). Samples of phytoplankton, periphyton, sediment and benthic biota were collected once a month from January 2012 to December 2012. Phytoplankton was collected using $20-\mu \mathrm{m}$-mesh nets, periphyton was scrubbed from stones, surface sediments were collected by means of a Van Veen Grab (with triple repetition) and benthos samples were obtained by sieving sediment through $0.5 \mathrm{~mm}$ mesh.

Additional samples of boulder clay and sand from the cliff at Gdynia Orlowo (Fig. 1) were collected during selected months characterised by intense rain and storms

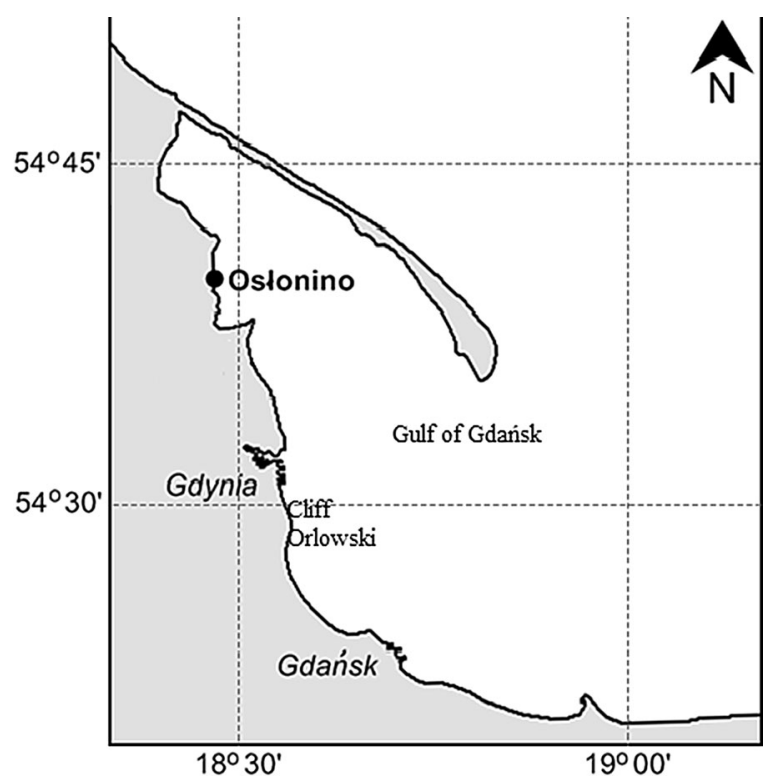

Fig. 1 Map of the study area 
at sea. Seawater samples were also taken from the coastal zone adjacent to the cliff. Over the course of the study period, 5 months fulfilled the conditions mentioned above (intense rain and storms at sea): December 2011, January 2012, March 2012, October 2012 and November 2012. Ten samples of sedimentary material were collected once from different parts of the Orlowo Cliff.

All samples were freeze-dried and homogenised, then analysed using an AMA 254 thermal desorption analyser. The detection limit for solid materials was set at $0.005 \mathrm{ng} \mathrm{g}^{-1}$. QA/QC included blank samples, replicates and reference materials: GBW 07314 (sediment) and BCR 279 (Ulva lactuca)-average error did not exceed $5 \%$ (Saniewska et al. 2010a). Seawater samples for mercury analysis were oxidised by adding $\mathrm{BrCl}$ and pre-reduced with hydroxylamine hydrochloride solution 1 hour prior to analysis by CVAFS (TEKRAN 2600, Canada), according to US EPA method 1631 (US EPA US Environmental Protection Agency 2002). Quality control procedures for water samples included the use of blanks and water spiked with mercury nitrate within a range of $0.5-25 \mathrm{ng} \mathrm{dm}^{-3}$ and produced adequate precision (1 \% RSD) and recovery (98-99\%). Each sample was analysed with triple or fivefold repetition and standard deviation was lower than $0.5 \mathrm{ng} \mathrm{g}^{-1} / 0.3 \mathrm{ng} \mathrm{dm}^{-3}$.

The division into thermally normal and anomal season was excerpted from Climate Monitoring Bulletin issued by the Institute of Meteorology and Water Management-National Research Institute (http://www. imgw.pl/extcont/biuletyn_monitoringu/). This division was made on the basis of data collected during the years 1951-2010 period. Winter 2012 was described as being a thermally normal season, spring and autumn of the same year: anomal warm season and the summer; warm season.

Basing on the meteorological data and information when the heat and power plants starts and ends, two sampling periods were distinguished - heating season (October-end of April) and non-heating season (May - end of September).

Biomass of phytoplankton was determined with an inverted microscope (Nikon TMS, Tokyo, Japan) according to the Utermöhl method (Edler 1979) and HELCOM recommendations (Olenina et al. 2006). Water samples for microscopic analysis of the phytoplankton were preserved using Lugol's solution (1\%).

Based on the weight of dried phyto, and zoobenthos, and the surface of collected sediment, biomass was then ascertained.

\section{Results and Discussion}

\section{$3.1 \mathrm{Hg}$ in the Atmosphere}

Mercury concentration in the air of the coastal zone is governed mostly by the origins of air masses (i.e., maritime or continental) as transformations of gaseous mercury to particulate form favour warm and humid marine air, in which chlorine and bromine ions are abundant (Bełdowska et al. 2014). A mild winter tends to result in less fossil fuel combustion, which is considered to be the major source of mercury in the Southern Baltic (Bełdowska et al. 2007; Bełdowska et al. 2012). In the Gulf of Gdansk area, during the very cold winter of 2006 (average temperature $-1.4{ }^{\circ} \mathrm{C}$; minimum $-30{ }^{\circ} \mathrm{C}$ ), average $\mathrm{Hg}$ concentrations in the particles in the air equalled $479 \mathrm{pg} \mathrm{m}^{-3}$, while in 2008 , when the winter was substantially warmer (average temperature $4.8{ }^{\circ} \mathrm{C}$; minimum $-1{ }^{\circ} \mathrm{C}$ ), a 20 -fold lower $\mathrm{Hg}$ concentration of $21 \mathrm{pg} \mathrm{m}^{-3}$ was measured (Bełdowska et al. 2007; Bełdowska et al. 2012) (Fig. 2). The effect of a warm winter (in comparison with a very cold winter) on the mercury cycle, taking into account only dry deposition flux, is an eightfold decrease of annual $\mathrm{Hg}$ atmospheric deposition (Bełdowska et al. 2014). Since 1988 (when warm winters began to prevail), the average winter temperature has been reported to exceed the multiyear normal on 15 occasions (IMGW PIB Institute of Meteorology and Water Management National Research Institute 2013).

The influence of climate change can also be seen in the summer season. At this time, in the warm marine air, $\mathrm{Hg}(0)$ was most probably oxidised by halogen radicals to form $\mathrm{Hg}$ (II) and adsorbed on condensation nuclei, subsequently to be washed out from the atmosphere during rainfall. In months when a higher amount of precipitation occurred, the wet deposition of $\mathrm{Hg}$ was higher (Saniewska et al. 2014b). From July to August, more and more anomalies were noted to occur in terms of monthly precipitation totals and, in July 2012, this value reached $220 \%$ of the 1971-2000 normal period (IMGW PIB Institute of Meteorology and Water 
Fig. 2 Concentration of $\mathrm{Hg}$ in particulate matter in air over Gdynia during the heating and the non-heating season, 2005-2009 (based on Bełdowska et al. 2007, 2012)

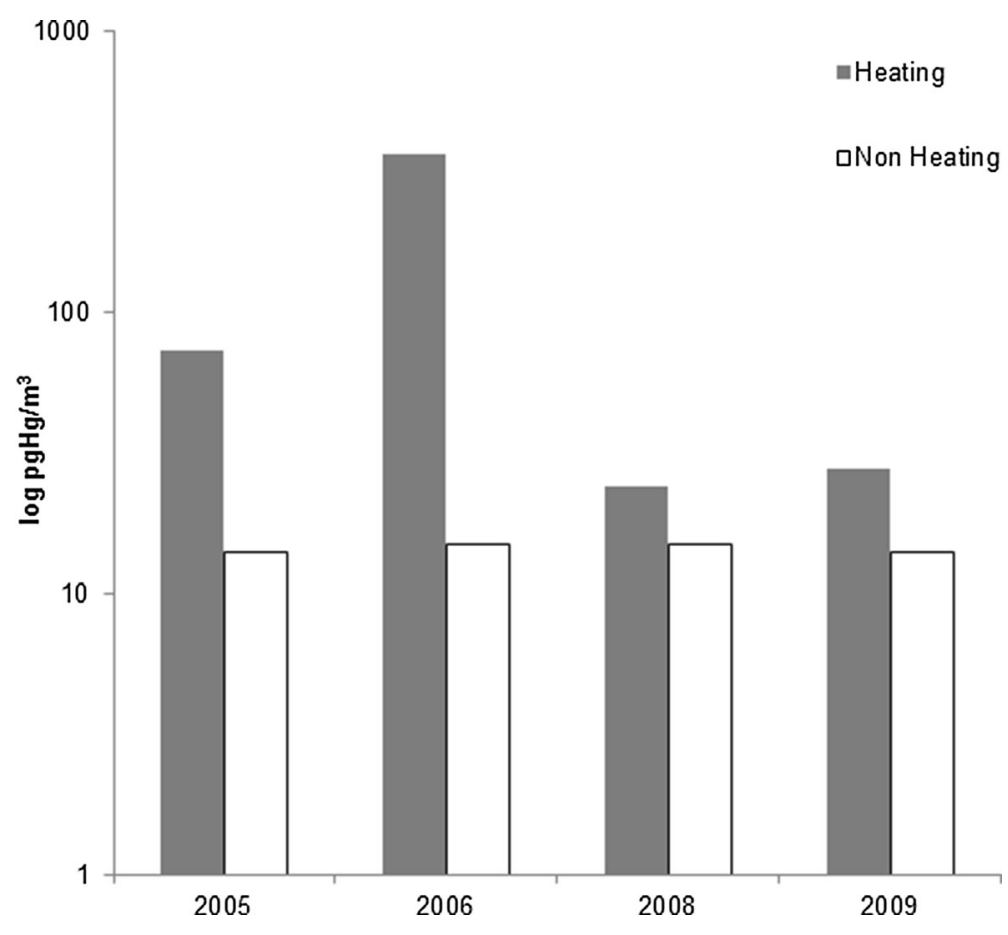

Management National Research Institute 2013). Assuming that the average concentration of $\mathrm{Hg}$ in the rain was comparable to the values measured in 2008 (Saniewska et al. 2014b), the increase in amount of precipitation contributed to several dozen percent increase in annual atmospheric $\mathrm{Hg}$ deposition.

\subsection{Hg Leaching from Soils}

An increasing frequency of extreme weather events has been observed in the Southern Baltic region (HELCOM 2013), leading to increase land erosion (frequently of forest soils, as in the areas of Oslonino, Gdynia Orlowo and Jastrzebia Gora) as a result of both strong winds and increased average wave height. As a consequence, increasing amounts of metals, hitherto stored in terrestrial reservoirs for many years, are reaching the sea in strong, distinct pulses (Bogacka 2003). In freshly eroded peat at Gdynia Orlowo, mercury concentration was found to range from 10 to $60 \mathrm{ng} \mathrm{g}^{-1}$ d.w., a concentration which is several dozen times higher than in the coastal sediments. Abrasion of the cliff in Orlowo causes around 47,000 $\mathrm{t} \mathrm{a}^{-1}$ of the material to be introduced into the Gulf of Gdansk (Bogacka 2003), which translates into about $2.6 \mathrm{~kg} \mathrm{Hg} \mathrm{a}^{-1}$
(Jędruch et al. 2013). Owing to this alone, a large load of mercury enters the coastal zone in a relatively short time, the mass of which is almost two times higher than the total annual amount of mercury transported into the Gulf of Gdansk by the Reda River (the second largest river discharging into the gulf, average flow; $4.3 \mathrm{~m}^{3} \mathrm{~s}^{-1}$ ) (Saniewska 2013). In the direct aftermath of a storm causing visible cliff erosion here, mercury concentration in the coastal water of the inner part of the Gulf of Gdansk increased from $0.7 \mathrm{ng} \mathrm{\textrm {dm } ^ { - 3 }}$ before the event to as much as $61.6 \mathrm{ng} \mathrm{dm}^{-3}$ after.

In the Gulf of Gdansk area, intensive rainfall and more frequent floods contribute to the remobilisation of labile, land-based mercury species and their transport into the Baltic Sea. Metal leaching is additionally enhanced by low $\mathrm{pH}$ rainwater and in the coastal zone of the Baltic Sea, acid rains were found to prevail for the majority of the year (Siudek et al. 2006). More frequent heavy rainfalls also contribute to the leaching of mercury from land, where it has hitherto been deposited for decades. For example, during a extreme flood in 2010 (20 May-19 June 2010), an estimate of the mercury load which was introduced to the Gulf of Gdansk as a direct result was equal to $75 \%$ of the total mercury load for that year (Saniewska et al. 2014a). 


\subsection{Hg in Seawater}

When a thermally normal winter starts later in the year, thereby prolonging the warm season, phytoplankton blooms may be observed in late autumn and even in early calendar winter (ŁysiakPastuszak et al. 2011). Such was the case in autumn 2012 (phytoplankton was present until December) and, in this situation, mercury entering the coastal zone with atmospheric deposition, the concentration of which is higher at this time of the year (Fig. 2), did not deposit on the bottom of the reservoirs but was accumulated by algae. Consequently, the concentration of mercury determined in phytoplankton during the heating season (especially in autumn) was higher than in the nonheating season (Fig. 3a). Increasing of the $\mathrm{Hg}$ concentration in the phytoplankton in late autumn or early spring was also observed during studies conducted at coastal zone of the Gulf of Gdansk in years 2006-2008 (Saniewska et al. 2010b). Elevated metal concentration in phytoplankton and high biomass of them resulted in raised concentration of $\mathrm{Hg}$ in the first link of trophic web (Fig. 3b). Any period of extended presence regarding the former can substantially enhance mercury transfer up the food chain of the Baltic Sea per annum.

Elevated concentrations of $\mathrm{Hg}$ during the thermally anomal warm autumn of 2012 were also observed in the peryphiton gathered from stones (Fig. 4), the average $\mathrm{Hg}$ concentration at this time being three times higher than during the thermally normal winter. Therefore, over the course of a warm year, even if $\mathrm{Hg}$ input to the southern Baltic Sea is observed to decrease (Bełdowska et al. 2012), the mercury load entering the food web may still exceed that of a year considered to be thermally normal. During the last 10 years, seven autumn seasons were deemed to be warmer than thermally normal (IMGW PIB Institute of Meteorology and Water Management National Research Institute 2013).

\subsection{Hg in the Sediments}

Climate change in the Polish coastal zone manifests itself in the shortening of icing periods (IMGW PIB Institute of Meteorology and Water Management
National Research Institute 2013), which affects the fluxes of chemicals in the surface sediments of the coastal zone. In the anomal warm autumn of 2012, an extended presence of phytoplankton was observed and, as a result, an increased amount of dead organic matter (decaying phytoplankton) sank to the bottom of the gulf. Consequently, $\mathrm{Hg}$ bound to sedimentary organic particulate matter $\left(\mathrm{Hg}_{\mathrm{LOI}}\right)$ was found to be proportional to $\mathrm{Hg}$ in suspended particulate matter $\left(\mathrm{Hg}_{\mathrm{SPM}}\right)(\mathrm{r}=0.75$, $p<0.05$ ) (Bełdowski et al. 2013). Benthic organisms, also experiencing intensive growth as a result of the warm autumn, were then bioaccumulated the $\mathrm{Hg}$ (Fig. 5) and thus a larger mercury load was made available to higher trophic levels. During this period, the concentration of $\mathrm{Hg}$ measured in benthos biomass (phyto- and zoobenthos) was five times higher than that of a thermally normal winter. Similarly observations were conducted in previous years (2006-2008): The highest concentration of $\mathrm{Hg}$ in phytobenthos was measured during winter without ice cover (Saniewska et al. 2010a).

Sediments, which act as a natural sink for heavy metals in the marine environment, contain historical deposits of metals. In the Baltic Sea, sedimentation rate is quite low (1-2 $\mathrm{mm} \mathrm{a}^{-1}$ ) (Bełdowski and Pempkowiak 2009) and mercury deposited during the past 50 years therefore rests in the uppermost $10 \mathrm{~cm}$ of its sediments. As this is close to sediment mixing depth, which in this area reaches up to $8 \mathrm{~cm}$ below the sediment water interface, it is possible for such mercury deposits to interact with near bottom water. Based on studies conducted in the years 1998-2002, due to a range of biochemical and physical processes, such as organic matter diagenesis, porewater diffusion and resuspension of unconsolidated surface sediments, about $50 \%$ of mercury deposited onto the floor of the Gdansk Basin is reemitted from marine sediments back into the water column (Bełdowski et al. 2009). In this current situation, the equilibria between processes responsible for the formation of stable mercury compounds, and the reemission of mercury back into water column has almost been reached. As a result, if the input of mercury to sediments increases further (with floods, land erosion and dead organic matter), its remobilisation may be expected to increase from several to several dozen percent more than the increase of input. Diffusive fluxes of $\mathrm{Hg}$ in the 

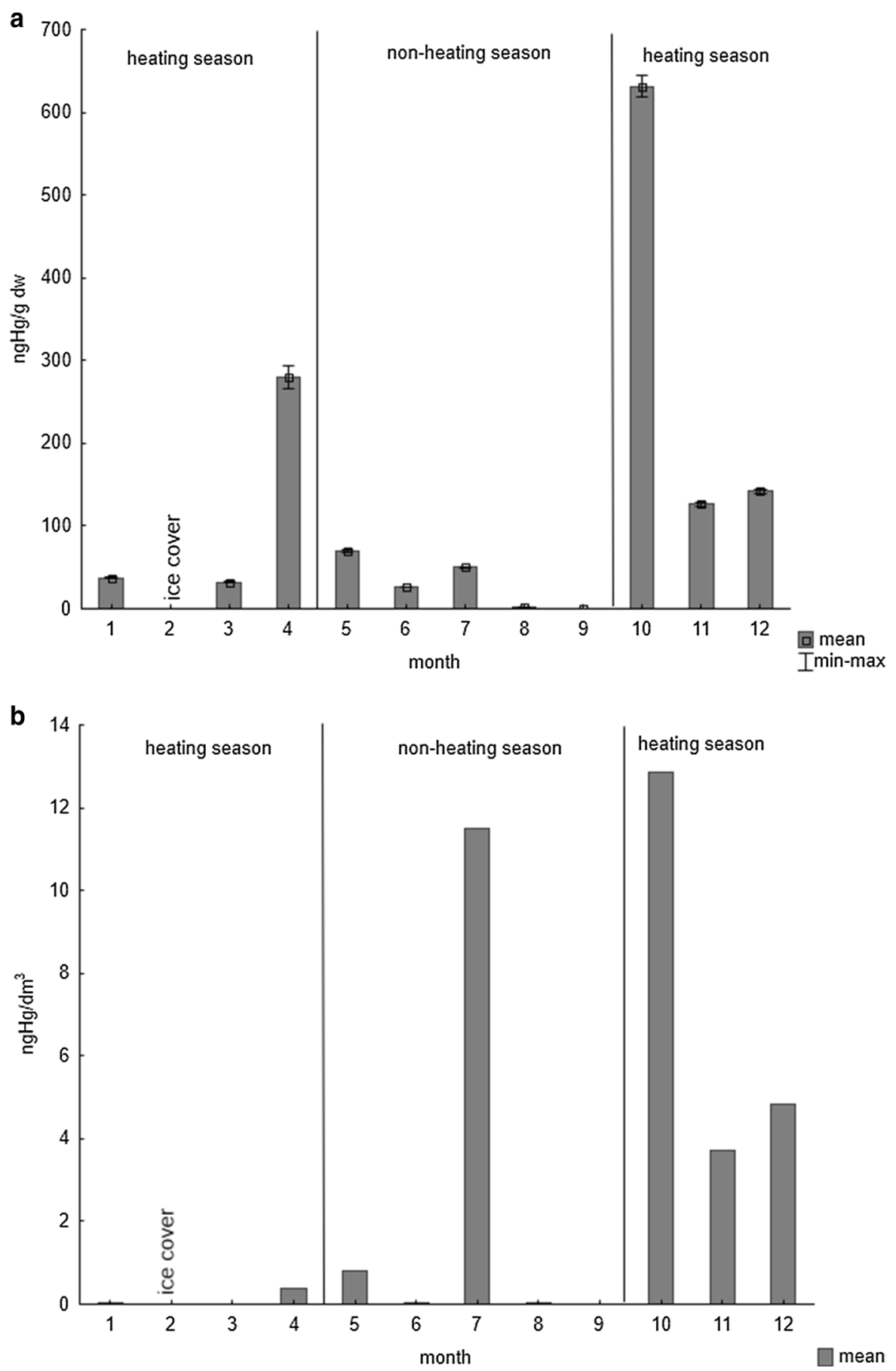

Fig. 3 Concentration of Hg: a in phytoplankton (ng g ${ }^{-1}$ d.w.); b in biomass of phytoplankton (ng dm ${ }^{-3}$ ) during 2012, in the Gulf of Gdansk

Gulf of Gdansk can reach $-5 \mathrm{ng} \mathrm{cm}^{-2} \mathrm{a}^{-1}$, while fluxes associated with sediment erosion might be as high as $-3.3 \mathrm{ng} \mathrm{cm}^{-2} \mathrm{a}^{-1}$, and this is close to the net accumulation of mercury $-5.5 \mathrm{ng} \mathrm{cm}^{-2} \mathrm{a}^{-1}$ (Bełdowski et al. 2009). Additionally, changes to environmental conditions on the sea bottom (as a result of climate change), such as increased supply of organic matter, decay of massive phytoplankton blooms on the seafloor leading to oxygen deficit and growth of sulfur reducing bacteria, and changes in 


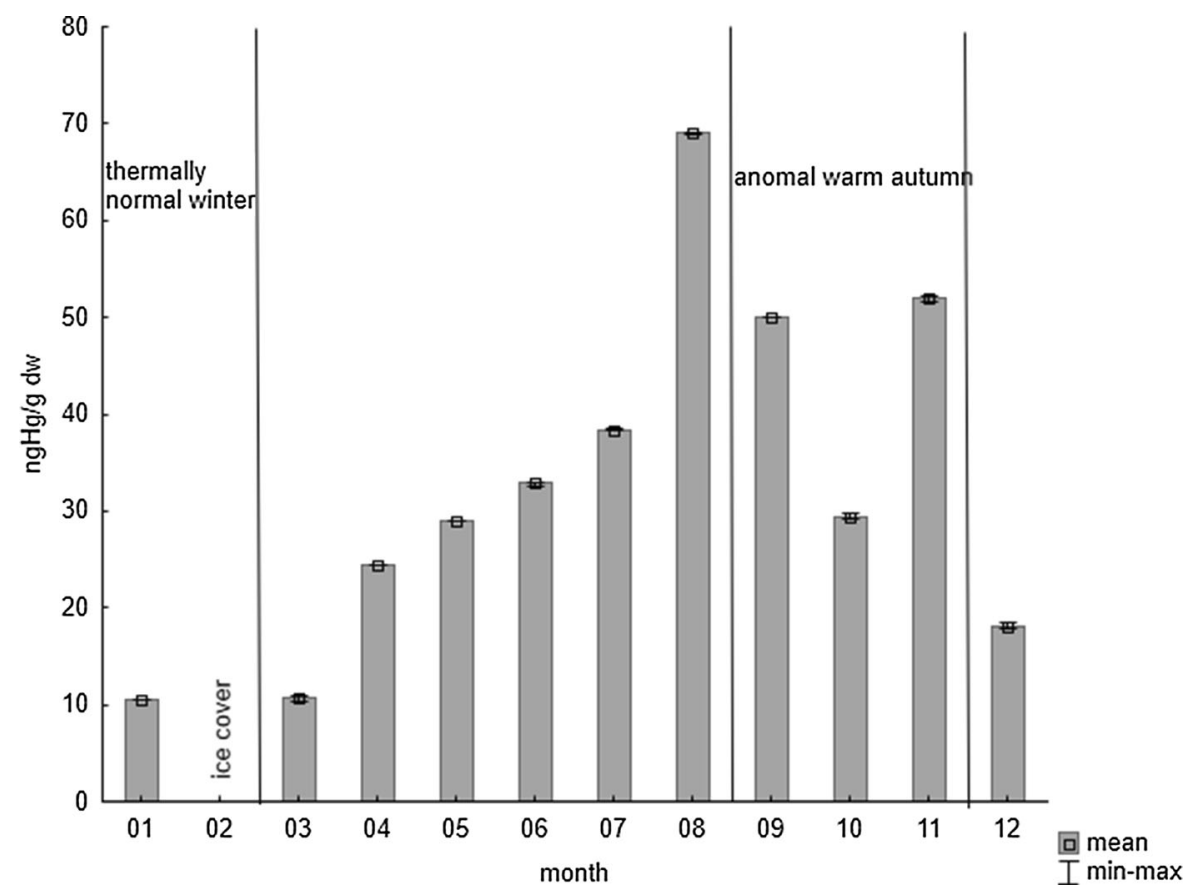

Fig. 4 Concentration of $\mathrm{Hg}$ in periphyton from stones (ng $\mathrm{g}^{-1}$ d.w.) during 2012, in the Gulf of Gdansk

salinity, may increase the intensity of organic matter diagenesis yet further. It is therefore highly conceivable that, in the future, marine sediments could become a significant and diffuse source of mercury without any reasonable means of control. Consideration of such a scenario is especially important with regards to the Gdansk Basin, where previous research has indicated high contents of labile mercury species in sediments and near-bottom suspended matter (Bełdowski and Pempkowiak 2007; Bełdowska et al. 2013).

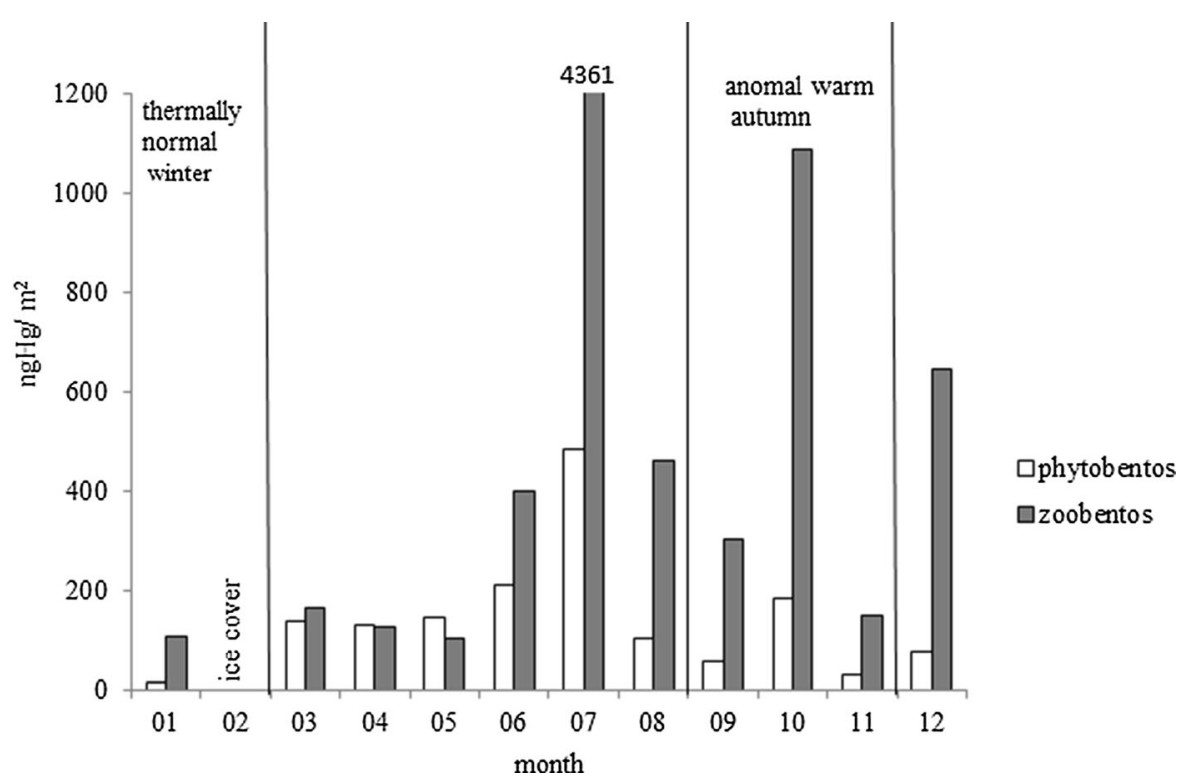

Fig. 5 Concentration of $\mathrm{Hg}$ in biomass of phytobentos and zoobentos $\left(\mathrm{ng} \mathrm{m}^{-2}\right.$ ) during 2012, in the Gulf of Gdansk 


\section{Conclusion}

Mercury input from atmosphere, land and marine sediments to the waters of the Southern Baltic coastal zone is highly dependent on changing meteorological parameters. These include variation in seasonal temperature, shortening of the icing period and frequency of extreme weather events and, in the future, such climate changes may result in an uncontrollable increase of bioavailable mercury in the seawater. An anomal or extremely warm winter, such as was experienced in the Southern Baltic in 2008, undoubtedly contributes to a significant reduction in $\mathrm{Hg}$ dry deposition fluxes. At the same time, however, $\mathrm{Hg}$ entering seawater is retained in the trophic chain to a larger extent than it would be during a thermally normal winter. Lack of icing, plankton blooms and benthic development in late autumn or even winter, maintain $\mathrm{Hg}$ bioavailability for an extended time period in comparison with that of a thermally normal season. In addition, benthic organisms contribute to the remobilisation of $\mathrm{Hg}$ from sediments where it has been deposited for many years. Floods and storms also contribute to the remobilisation of metals, generally from historical land-based deposits. Such processes are of major significance to marine organisms inhabiting the coastal zone and estuaries, as they cause toxic substances to be introduced into the sea within a relatively short time. The results presented as part of this study indicate that climate change can indeed enhance mercury coast to basin fluxes, as well as the transfer of bioavailable forms of this metal into the food web; however, they do not allow for proper quantification of those processes. Future studies concerned with mercury behavior in the temperate zone under influence of climate change need to be extended to plankton and benthos species composition, preferably during periods which feature abnormally high temperatures in autumn, winter and spring. It is therefore intended that further connected research, which is planned for 2012-2014 in the area of the Gdansk Basin and which will be conducted within the framework of a National Science Centre (NSC) project, will both address these requirements and provide some quantification of observed fluxes.

Acknowledgments This study has been performed within the framework of a National Science Centre project: No. 2011/01/B/ ST10/07697.

The author wish to express their gratitude to: Justyna Kobos from the Biochemical Ecology Of Microorganisms Laboratory, Department of Marine Biology and Ecology, Institute of
Oceanography, University of Gdansk, for analysis of phytoplankton biomass; Aleksandra Zgrundo from the Marine Environment Bioindication Laboratory, Department Of Marine Ecosystems Functioning, Institute of Oceanography, University of Gdansk, for analysis of phytobenthos biomass; and to Marta Szubska from the Department of Marine Chemistry and Biochemistry, Institute of Oceanology, Polish Academy of Science, for analysis of $\mathrm{Hg}$ in seawater.

Open Access This article is distributed under the terms of the Creative Commons Attribution License which permits any use, distribution, and reproduction in any medium, provided the original author(s) and the source are credited.

\section{References}

Barkay, T., \& Poulain, A. J. (2007). Mercury (micro) biogeochemistry in polar environments. FEMS Microbiology Ecology, 59, 232.

Bełdowska, M., Falkowska, L., Siudek, P., Gajecka, A., Lewandowska, A., Rybka, A., \& Zgrundo, A. (2007). Atmospheric mercury over the coastal zone of the Gulf of Gdansk. Oceanological and Hydrobiological Studies, 36(3), 9-18.

Bełdowska, M., Jędruch, A., Bełdowski, J., Szubska, M. (2013). Mercury concentration in the sediments as a function of changing climate in coastal zone of Southern Baltic Sea preliminary results. E3S Web of Conferences 1, 06002, doi: 10.1051./e3sconf/20130106002.

Bełdowska, M., Saniewska, D., Falkowska, L., \& Lewandowska, A. (2012). Mercury in particulate matter over Polish zone of the southern Baltic Sea. Atmospheric Environment, 46, 397404.

Bełdowska, M., Saniewska, D., \& Falkowska, L. (2014). Factors influencing variability of mercury input to the southern Baltic Sea. Marine Pollution Bulletin, 86, 283-290.

Bełdowski, J., Bełdowska, M., Jędruch, A., Szubska, M., Kobos, J., Mudrak-Cegiołka, S., et al. (2013). Mercury in the coastal zone of southern Baltic Sea as a function of changing climate - preliminary results. Edinburgh: The 11th International Conference on Mercury as a Global Pollutant. July 28th August 2nd 2013.

Bełdowski, J., \& Pempkowiak, J. (2007). Mercury transformations in marine coastal sediments as derived from mercury concentration and speciation changes along source/sink transport pathway (Southern Baltic). Estuarine Coastal and Shelf Sea Science, 72, 370-378.

Bełdowski, J., \& Pempkowiak, J. (2009). Mercury concentration and speciation changes in the course of early diagenesis in marine coastal sediments (Southern Baltic Sea). Journal of Marine and Freshwater Research, 60, 745-757.

Bełdowski, J., Pempkowiak, J., \& Miotk, M. (2009). Mercury fluxes through the sediment water interface and bioavailability of mercury in Southern Baltic Sea sediments. Oceanologia, 51, 263-285.

Bogacka, A. (2003). Input of mineral suspended matter into the Gulf of Gdańsk Walters, due to abrasion of Orłowo Cliff (p. 69). Poland: PhD Thesis University of Gdańsk. 
Carrie, J., Sanei, H., Stern, G., A., Wang, F. (2009a.) Mercury in the Mackenzie River Basin: Source, speciation and projected response to climate change. 9th International Conference on Mercury as a Global Pollutant, abstract S09-02.

Carrie, J., Sanei, H., Wang, F., Stern, G., A. (2009b.) The impact of climate change on mercury in burbot from the Mackenzie River, Canada. 9th International Conference on Mercury as a Global Pollutant, abstract S09-03.

Douglas, T. A., Loseto, L. L., Macdonald, R. W., Outridge, P., Dommergue, A., Poulain, A., et al. (2012). The fate of mercury in Arctic terrestrial and aquatic ecosystems, a review. Environmental Chemistry, 9(4), 321-355.

Ebinghaus, R., Turner, R. R., Lacerda, L. D., Vasiliev, O., \& Salomons, W. (1999). Mercury contaminated sites. Berlin: Springer. 538 .

Edler, L. (1979). Phytoplankton and chlorophyll: Recommendations on methods for marine biological studies in the Baltic Sea. Baltic Marine Biologists Publication, 5, 1-38.

Fjeld, E., \& Rognerud, S. (2011). Increasing mercury concentrations in perch (perca fluviatilis) in south-east Norway from 1991 to 2008. 10th International Conference on Mercury as a Global Pollutant, abstract WS12-O5, pp. 101.

HELCOM, (2013). Climate change in the Baltic Sea Area: HELCOM thematic assessment in 2013. Balt. Sea Environ. Proc. No. 137.

Heimbürger, L. E., Cossa, D., Marty, J. C., Migon, C., Averty, B., Dufour, A., \& Ras, J. (2010). Methyl mercury distributions in relation to the presence of nano- and picophytoplankton in an oceanic water column (Ligurian Sea, North-western Mediterranean). Geochimica et Cosmochimica Acta, 74(19), 5549-5559.

Hermanns, Y., Martinez-Cortizas, A., Kilian, R., Arz, H., Stein, R., Biester, H. (2011). Climate components in the aquatic mercury cycle. 10th International Conference on Mercury as a Global Pollutant, abstract WS12-O1, pp. 131.

IMGW PIB (Institute of Meteorology and Water Management National Research Institute). (2013). Bulletin (http://www. imgw.pl/extcont/biuletyn_monitoringu). Accessed December 2013.

Jędruch, A., Bełdowska, M., Falkowska, L., Perec M., Grzesińska K. (2013). The impact of coastal erosion on the mercury input into the Gulf of Gdańsk. Conference Geological processes of the coastal zone of the sea, 5-6 June 2013, Gdynia, Poland.

Korzeniewski, K. (1993). Puck bay (p. 532). Gdańsk: Fundacja Rozwoju Uniwerystetu Gdańskiego. in polish.

Korpinen, S., Laamanen, M., Andersen, J.H., Asplund, L., Berger, U., Bignert, A., et al. (2010). Hazardous substances in the Baltic Sea - An integrated thematic assessment of hazardous substances in the Baltic Sea. Balt. Sea Environ. Proc. No. 120B; Helsinki Commission, Finland, 119 p.

Kożuchowski, K. (2009). Contemporary climate warming in Poland. Papers on Global Change, 16, 41-53.

Łysiak-Pastuszak, E., Lewandowski, L., Kraśniewski, W. (2011). Influence of climate change on the spatial and temporal structure of algal blooms. Conference on Climate Change and its expected impact in the Polish coastal zone, 31 May 2011 Gdynia.

Olenina, I.S., Hajdu, A., Andersson, L. Edler, N., Wasmund, S., Busch, J., et al. (2006). Biovolumes and size-classes of phytoplankton in the Baltic Sea. Baltic Sea Environment Proceedings (Helsinki Commission, Helsinki) 106, 1-144.

Pacyna, E. G., Pacyna, J. M., Sundseth, K., Munthe, J., Kindbom, K., Wilson, S., et al. (2010). Global emission of mercury to the atmosphere from anthropogenic sources in 2005 and projections to 2020. Atmospheric Environment, 44, 24872499.

Rydberg, J., Klaminder, J., Rosén, P., Bindler, R. (2011). A warming climate increases export of mercury from subarctic permafrost mires to lakes. 10th International Conference on Mercury as a Global Pollutant, abstract WS12-O3, pp. 273.

Sanei, H., Outridge, P., Stern, G., Wang, F., Goodarzi, F. (2009). Mercury, organic matter, and climate change; unraveling the dilemma of the sedimentary mercury records. 9th International Conference on Mercury as a Global Pollutant, abstract S09-07.

Saniewska, D. (2013). Pathways of Hg migration into the Coastal Zone of the Gulf of Gdańsk. Gdańsk: PhD Thesis, University of Gdańsk.

Saniewska, D., Bełdowska, M., Bełdowski, J., Jędruch, A., Saniewski, M., \& Falkowska, L. (2014a). Mercury loads into the sea associated with extreme flood. Environmental Pollution, 191, 93-100.

Saniewska, D., Bełdowska, M., Bełdowski, J., \& Falkowska, L. (2014b). Mercury in precipitation at urbanized coastal zone of Baltic (Poland). Ambio, 43, 871-877.

Saniewska, D., Bełdowska, M., Bełdowski, J., Saniewski, M., Kwaśniak, J., \& Falkowska, L. (2010a). Distribution of mercury in different environmental compartments in the aquatic ecosystem of the coastal zone of Southern Baltic Sea. Journal of Environmental Sciences, 22(8), 1-7.

Saniewska, D., Bełdowska, M., Bełdowski J., Saniewski, M., Szubska, M., Romanowski, A., et al. (2010b). Mercury concentration in selected environmental compartments of the coastal zone of the southern Baltic Sea. II Conference Mercury in the environment - identification of threats for human health, 12-14.05.2010, Gdynia, Poland.

Siudek, P., Falkowska, L., Lewandowska, A., Pryputniewicz, D., Bełdowska, M., \& Gic, P. (2006). Chosen anions and cations in the precipitation over the coastal zone of the Gulf of Gdańsk. Ocenological and Hydrobiological Studies, 35(1), 39-53.

Stern, G., Sanei, H., Roach, P. (2009). The interrelated variations of mercury and aquatic organic matter in a centennial-scale sedimentary record of the sub-arctic Kusawa Lake in Yukon, Canada. 9th International Conference on Mercury as a Global Pollutant, abstract S09-11.

Stern, G. A., Macdonald, R. W., Outridge, P. M., Wilson, S., Chételat, J., Cole, A., Hintelmann, H., et al. (2012). How does climate change influence arctic mercury? Science of the Total Environment, 414, 22-42.

US EPA (US Environmental Protection Agency). (2002). Method 1631, Revision E: Mercury in water by oxidation, purge and trap, and cold vapor atomic fluorescence spectrometry. US Environmental Protection Agency, Office of Water 4303, EPA-821-R-02-019. 46.

Zahir, F., Rizwi, S. J., Haq, S. K., \& Khan, R. H. (2005). Low dose mercury toxicity and human health. Environmental Toxicology and Pharmacology, 20, 351-360. 